\title{
Council of Ministers of Education, Canada (CMEC) and the First Nation Education in Canada: International Implications
}

\author{
Ron S. Phillips \\ Nipissing University, Canada
}

\begin{abstract}
The Council of Ministers of Education, Canada (CMEC) ignores the federal government of Canada's constitutional responsibilities in education. It incorrectly references the Constitution Act of 1867 to state that education in Canada is constitutionally an exclusive provincial/territorial responsibility. The CMEC represents Canada with international organizations (e.g., Organization for Economic Cooperation Development (OECD) and United Nations Educational, Scientific and Cultural Organization (UNESCO), and at international education conferences and meetings. The international community has no reason to question the federal government on education due to the CMEC's insistence that it is an exclusive provincial/territorial responsibility. The purpose of this paper is to examine the refusal of the CMEC to acknowledge that the Canadian constitution gives education to both the federal and provincial/territorial governments. This refusal results in a very distorted image of education in Canada to both Canadians and to the world community. Canada's rankings in national comparisons, i.e., Programme of International Student Assessment (PISA) would drop dramatically if federal schools (i.e., First Nation) were used.
\end{abstract}

\section{Introduction}

The Council of Ministers of Education, Canada (CMEC) is an organization comprised of the provincial and territorial ministers of education. It was established in 1967. The organization describes itself as "an arm of provincial ministers of education, CMEC is the mechanism for consulting on matters of mutual interest; representing Canadian education internationally; providing liaison with various federal departments; and cooperating with other national educational organizations." [1] .

The assumption of the provincial and territorial governments into the international education sphere may be traced back to the document "Understanding between the Council of Ministers of Education,
Canada and the Department of External Affairs". This agreement allows the CMEC to represent Canada at "education-related international activities" [2]. This document also outlines the "cooperative relationship" between these two organizations. The agreement emphasized the division of jurisdictions as it was stressed "All such statements will take full account of federal jurisdiction for external affairs and provincial jurisdiction in relation to education". In the preamble of Section B - Mandate titled Federal-Provincial Consultative Committee on Education-Related International Activities "Noting the jurisdiction of the provinces in the field of education, ...” [2]

This last statement of provincial jurisdiction in education is incorrect. The purpose of this paper is to examine the refusal of the CMEC to acknowledge that the Canadian constitution (i.e., Constitution Act, 1982) gives education to both the federal and provincial/territorial governments. This refusal results in a very distorted image of education in Canada to both Canadians and to the world community. Canada's rankings in national comparisons would drop dramatically if federal schools (i.e., First Nations) were used.

\section{Literature Review}

On July 18, 2014, I opened the English language home web page (http://www.cmec.ca/en/) of the Council of Ministers of Education, Canada (CMEC) and was welcomed to the site with the statement "Welcome to the Council of Ministers of Education, Canada - Providing national leadership in education for over 40 years." [3]

Under the heading 'Education in Canada', a map of Canada indicated that readers should "Click on a province or territory for information". For example, after clicking on Ontario, information on Ontario's Ministry of Education and the Ministry of Training, Colleges and Universities, names of Ministers, web pages, telephone and fax numbers follow. Similar information is provided on other provinces and territories.

In the same block as the map there was another smaller heading to click. It was titled 'Canada-Wide 
Information'. After clicking on it, the following statement came on the screen:

In Canada, there is no federal department of education and no integrated national system of education. Within the federal system of shared powers, Canada's Constitution Act o 1867 provides that "[I]n and for each province, the legislature may exclusively make Laws in relation to Education." In the 13 jurisdictions - 10 provinces and 3 territories, departments or ministries of education

are responsible for the organization, delivery, and assessment of education at the elementary and secondary levels, for technical and vocational education, and for postsecondary education. [3]

The CMEC web page also describes the international mandate and activities of the organization. Their involvement in international government organizations is due to their 'exclusive responsibility' in education. Essentially, their role is to speak for Canada on education matters and issues:

International relations have always been an important element of CMEC activities, reflecting its role as the collective voice of the provinces and territories in educational matters that involve international and intergovernmental organizations.

Jurisdiction remains an important issue, given the exclusive responsibility of the provinces and territories and of the federal government in the conduct of foreign affairs. [3]

CMEC represents Canada at "appropriate meetings and conferences of international organizations". The web page notes "At many events, ministers of education lead the Canadian delegation, speaking to the issues at hand and presenting Canadian experience and suggestions for action." [3].

The CMEC's international involvement is focused on the Organization for Economic Co-operation and Development (OECD), United Nations Educational, Scientific and Cultural Organization (UNESCO), and the Commonwealth. However, it is also works with other international organizations, i.e., the Organization of American States (OAS), APEC Human Resource Development Working Group Education Network (EdNet), Southeast Asian Ministers of Education Organization (SEAMEO), council of Europe, G8, and United Nations Economic Commission for Europe (UNECE).

The web page also provides information from the Organization for Economic Co-operation and Development's (OECD) Education at a Glance:
Highlights for Canada. Canada is identified as "one of the most well-educated countries in the world" [4]. The report is described as an "annual report on a set of internationally comparable indicators" that "enable educational policy makers and practitioners alike to see their education systems in light of other countries' performance ..." [4].

The report indicates that Canadian education information has been "collected from the provincial/territorial ministries/departments of education and aggregated to the Canada level ..." Canada has high scores in a number of the indicators. For example, "Canada has the highest proportion of 25 to 64 year olds with tertiary education (college and university) among OECD countries"; completion of secondary education - "at 85 per cent, Canada is above the OECD." [4].

To summarize, the CMEC web site states unequivocally that education is constitutionally (i.e., The Constitution Act, 1867) the exclusive responsibility of the provinces and territories. CMEC map does not have a spot to click for Ottawa or for the federal government. Since the federal government of Canada has constitutionally no education responsibilities, the CMEC represents Canada in internationally intergovernmental organizations in education matters. The quotations from the Constitutional Act, 1867 appear to support that education is exclusive to the provinces and territories. Finally, the CMEC documents indicate that education in Canada is doing quite well as it scores high in international comparisons.

CMEC's web page, map, and statements of provincial exclusivity in education are factually wrong and give a misleading picture of Canadian education to Canadians and to the world community. It appears that the CMEC has decided to ignore the Constitution Act, 1982, as well as parts of the Constitution Act, 1867 and federal legislation.

\section{Provincial 'Exclusivity'?}

Many CMEC's reports make a reference to the Constitution Act, 1867 to emphasize the exclusivity of provincial jurisdiction in education. The reference is usually: "Within its federal system of shared powers, Canada's Constitution Act, 1867, provides that $[I\} n$ and for each Province may exclusively make Laws in relation to Education ..." [5], [6], [7], [8].

Similar statements may be found throughout other CMEC reports. These statements include the following quotes: "Education in Canada is the responsibility of the 13 provinces and territories" [9], "Canada is a federation, and education is the constitutional responsibility of the ten provinces and three territories" [10], "Whereas education in Canada is a provincial responsibility" [11], and, "Whereas education as a provincial/territorial jurisdiction," [12]. 


\section{The Federal Government and Education}

CMEC has ignored federal responsibilities in education found in the Constitution Act, 1867 and 1982, as well as the Indian Act. The Constitution Act, 1867, Section 93 did assign the power to the provinces to "exclusively make Laws in relation to Education" [25]. However, the same constitution's Section 91-24 gave responsibility of "Indians, and Lands reserved for the Indians" to the federal government of Canada." [12]

For some reason, the CMEC has forgotten that in 1982 when the constitution was patriated and renamed (i.e., Constitution Act, 1982), two parts were added. Part I was the Charter of Rights and Freedoms. Part II was Rights of the Aboriginal Peoples of Canada [13]. This part included the clause, Section 35. (1) The existing aboriginal and treaty rights of the aboriginal peoples of Canada are hereby recognized and affirmed. Education was a part of each of the numbered treaties. For example, Treaty 5's education clause was:

And further, Her Majesty agrees to maintain schools for instruction in such reserves hereby made as to Her Government of the Dominion of Canada may seem advisable, whenever the Indians of the reserve shall desire it. [14]

The federal government's Indian Act also sets out the federal minister of Aboriginal Affairs and Northern Development Canada's authority in education. Section 114(2) indicates "The Minister may, in accordance with this Act, establish, operate and maintain schools for Indian children." [15]

In summary, a review of the Constitution Acts, 1867 and 1982 finds that education in Canada is the constitutional responsibility of both the federal and provincial/territorial governments. Provincial and territorial governments have constitutional responsibilities for education within their own jurisdictions (i.e., province/territory). The federal government of Canada has constitutional responsibilities in education within its jurisdiction (i.e., First Nation) across Canada.

\section{First Nations Schools: The Reality}

There are 518 First Nation schools across Canada (Standing Senate Committee on Aboriginal Peoples, 2011). In 2011-2012, the federal government's education budget for 117,500 First Nation elementary and secondary students was $\$ 1.51$ billion. These students attend one of three types of schools. Approximately, 60\% attended First Nation schools, $36 \%$ attended provincial schools, and $4 \%$ attended private or federal schools [16]. These 518 First Nation schools, as well as their students have been ignored by the CMEC. Constitutionally and practically, they do not exist to the CMEC.

First Nation schools across Canada have in the past and currently face many difficult challenges. For example, an early education report from AANDC on the education programs offered in First Nation schools in Manitoba indicated that funding supports for provincial programs such as special education, high school programming, and consulting support services were not available. The report also noted "... the failure of our education system to meet the needs of Indian students and the Indian people." [17]

On April 13, 2010, Ms. Cram, Assistant Deputy Minister, Education and Social Development Programs and Partnerships, AANDC, spoke to the Standing Senate Committee on Aboriginal Peoples. Ms. Cram admitted that AANDC does not have the education expertise found within the provincial/territorial systems as she stated "We do not claim to have expertise in post-secondary or kindergarten-to-Grade 12 education." [18]

Ms. Cram's presentation highlighted the absence of an education system for First Nation students across Canada. She noted "we do not have a system of education" [18]. This non-system has consequences for First Nation students. She stated that in 2002-03 only $29 \%$ of First Nation students graduated from Grade 12 compared to $75 \%$ for nonAboriginal Canadians. She also noted that in 2006 only $7 \%$ of First Nation people had a university degree compared with $23 \%$ in the non-Aboriginal population.

Other reports have contrasted the education funding received by First Nations from the federal government with that received by provincial schools. One report comparing education funding for a First Nation tribal council with that a nearby provincial school division in Saskatchewan found that federal funding for second-level or support services in First Nation or tribal council "lags significantly behind resource commitments in provincial-operated school divisions." [19]

In 2011, the province of Ontario's Office of the Chief Coroner issued a report on youth suicides on Pikangikum First Nation in northwestern Ontario. Part of the report reviewed the First Nation education system. The education system in Pikangikum First Nation was encountering many challenges. Only 520 students out of approximately 800 - 1000 were enrolled in school. There were only 8 to 9 Grade 12 graduates each year. Teachers' salaries were lower than those offered to teachers in provincial schools. Teachers also lacked pension plans and professional development. Not surprisingly, teacher turnover was high. It was estimated that the students in the school were at least three years behind their age/grade level. 
The report also found that the education funding the First Nation received from the federal government was not comparable to provincial funding. For example, "in 2008-09, the estimated per pupil cost for a band-operated school was $\$ 4,127$. Compared to projected per pupil provincial funding of $\$ 9,976$ for the same period." [20].

The report found many education challenges both students and teachers. The school lacked the following: a gym, a library, tech or trade facilities, lockers, science facilities, a common gathering area, access for wheelchairs, outdoor recreational equipment and a playground, facilities for special education. The classrooms were in seventeen portables. The portables were poorly insulated. Some classes are overcrowded, i.e., 55 students in a Grade 8 class.

In an AANDC discussion guide on First Nation education, AANDC acknowledged that according to the OECD "Canada's education system is ranked among the highest in the world" [21]. The report noted the uniqueness of First Nation education as "First Nation children attending a school on reserve are the only children in Canada whose education is not governed by comprehensive education-specific legislation ..." [21]. This federal government department then ignored federal constitution responsibilities in education by stating "Provinces and territories are responsible for education in Canada." [21].

In 2011, the Standing Senate Committee on Aboriginal Peoples released a report "Reforming First Nations Education: From Crisis to Hope". The Committee also expressed concerns over "the current ad hoc, non-system" [22] of First Nation education. The report detailed how AANDC expects "First Nations to educate their students at levels comparable to provincial and territorial jurisdictions, and yet provides them with no meaningful supports by which to do so". First Nation schools are "lacking critical education supports". First Nations are the only Canadians who do not have a modern system of education" resulting in "uncounted numbers of First Nations children and youth who are receiving an education vastly unequal to their nonFirst Nations neighbor." [22].

\section{Misinformation}

As part of their mandate the CMEC represents Canada at intergovernmental organizations such as OECD and UNESCO. They also provide Canadian education information and statistics to these organizations. These organizations are given misinformation on education in Canada, i.e., education is constitutionally a provincial responsibility. For example, OECD's Programme for International Student Assessment (PISA) is an international educational assessment of 15 year-olds in many countries. Its purpose is to "assess whether students approaching the end of compulsory education have acquired the knowledge and skills that are essential for full participation in society" [23] in a report on PISA results noted "Schools on Indian reserves were excluded".

The results of this PISA indicated that Canada's education system was "strong" [24]. Only three countries outperformed Canada.

UNESCO's World Data on Education (2006) indicated "the administration of education is centred in the constitutionally secured right of the provinces and territories exclusive jurisdiction over education within the federated system of shared powers" [25]. The federal government is "responsible for education of Canada's Native peoples (registered Indians and Inuit people resident on a reserve) at the elementary and secondary levels ...". However, the report noted that the "Federal Government does not share in the exercise of direct power over education ...".

In a report to UNESCO on human rights education, the CMEC again asserted that education in Canada is constitutionally the responsibility of the provinces and territories. The Constitution Act of 1867 was used to assert "exclusive legislative responsibility for education for education is granted to the provinces of Canada" [26]. Later, under the heading Responsibility for Education, the Constitution Act of 1867 was again used to give constitutional responsibility to the provinces. The federal government was mentioned without the word 'constitutional' as it "shares responsibility with First Nations for the provision of elementary and secondary education to children ordinarily resident on a reserve ..." [26].

The report reviewed Canadian education legislation and principles, education standards, school governance and practice, learning environments, etc. It mentioned that an education law "in each jurisdiction specifies who is responsible or who is entitled to attend school". However, jurisdiction in this report only referred to the provinces and territories. The report also included a section on sources used in preparing the report. Not surprisingly, only provincial / territorial departments/ministries of education were included. The federal government was not listed.

In a 2010 report on the use of PISA results to improve education, the OECD noted "PISA represents a commitment by governments to monitor the outcomes of educational systems in terms of educational achievement on a regular basis and within an international agreed common framework" [27]. The report highlighted Australia's, Canada's, and Denmark's performance on PISA as being "strong and consistent".

In 2011, the Canadian Education Statistics Council (CESC) released a report on education indicators in Canada. The organization is comprised of Statistics Canada, a federal government department, and the CMEC. The CESC report 
references PISA 2009 and student achievement in Canada. It describes participation in PISA 2009 as students from the provinces. First Nation students were not included in PISA 2009 as "students of schools located on Indian reserves were excluded" [28]. The report also states "In Canada, education is the responsibility of the 10 provinces and territories". This is surprising as one of the joint partners of CESC is Statistics Canada, a federal government department.

Incorrect Canadian education statistics and information gathered by CMEC and later found in OECD and UNESCO reports may result in additional problems in educational research and publishing. Researchers may repeat the mantra that education in Canada is the exclusive constitutional responsibility of the provinces and territories For example, a book on cultural diversity for UNESCO's International Institute for Education Planning reported that "In the Canadian constitution, education is one of the areas under the responsibility of the provinces" [29].

Four years later, in 2012, an article that was published by UNESCO on racial and diversity in schools noted "In Canada, the area of education is under provincial and territorial jurisdiction" [30]. Again, such statements are factually wrong and give an incorrect information on education in Canada.

\section{Discussion}

The CMEC's narrow view of constitutional responsibility for education in Canada ignores the federal role. Such actions give a very distorted image of education in Canada to both Canadians and the world community. It has already been demonstrated that this misinformation is being used incorrectly by other education researchers and writers. This is wrong. Canada's constitution clearly assigns education to both the federal and provincial/territorial governments. Yet, the CMEC only considers provincial/territorial jurisdiction, schools, and students in their many reports, assessments, documents, and press releases.

Canadians may feel proud of their usual high world rankings of educational systems and student achievements in organizations such as the OECD, UNSECO, and CMEC. However, the high rankings are incorrect.

The CMEC's role in representing Canada in international organizations has several downsides. First, the numerous statements of 'provincial exclusivity in education' and the 1867 Constitution are factually wrong. Secondly, it gives international organizations and their members an inaccurate image of education in Canada.

The world community is given misinformation on the constitutional responsibilities in education in Canada. International governmental organizations such as UNESCO and the OECD would have no reason to question Canada being represented at international education conferences and forums provincial and territorial ministers of education due to the often repeated mantras of 'Constitution Act, 1867 ' and 'exclusive education responsibility'. These organizations would also have no reason to question 'Canadian' education statistics and information which purport to represent a panCanadian population base but which specifically excludes schools on First Nations throughout Canada. This is ironic, as federal or First Nations schools are the only national or pan-Canadian education system in Canada.

However, the provinces and territories are not alone in misleading Canadians and the world community. Serious questions must be asked of the federal government of Canada. Why does it allow federal departments to publish that 'education is the exclusive responsibility of the provinces and territories', when it is not true? Why are First Nation schools not included in education surveys? How can First Nation education be improved, if there is no base-line information?

The inability of the federal government to insist that First Nation schools be included in education surveys, as well as their allowing provincial/territorial education ministers to represent Canada in international education organizations and conferences gives an incorrect picture of education in Canada. It also indicates that the federal government has demonstrated a refusal to accept their constitutional responsibilities in education. It has essentially given up any pretense of caring about the education of First Nation children.

The reasons for the federal government to encourage the CMEC to gather and publish provincial/territorial education statistics and information as representing Canada are obvious. The federal government of Canada does not want Canadians and the world community to be aware of their shortcoming in First Nation education. The federal government of Canada has had constitutional responsibilities for First Nation education since 1867. Despite this, the government has shown no interest or inclination to improve the education of First Nation students living on reserves/First Nations across Canada. The result is a non-system of education that is poorly funded, offers few secondlevel support services, and has no legislative base. Canada's education rankings in the world would drop dramatically if Canada's only pan-Canadian system of education (i.e., First Nation/federal schools) represented Canada in the OECD's PISA and other assessments.

This drop in education world rankings may be the incentive that encourages the federal government of Canada to take its constitutional responsibilities in education seriously. World leaders and international organizations such as OECD and UNESCO may question Canada's education expertise and 
knowledge when they see the reality that confronts First Nation children as they go to their school every day.

\section{Recommendations}

It is time that the CMEC provide Canadians and the world community with correct information on 'constitutional' responsibilities for education in Canada. Federal government constitutional education responsibilities must be included in any description of education in Canada. The CMEC's web-site and home-page must have an area to click on to represent the federal government od Canada. The era of 'provincial exclusivity in education' in numerous CMEC documents and reports must end.

It is recommended that the following recommendations be implemented to ensure that 'Canadian' education statistics and information represent Canada:

1. The CMEC must acknowledge that the federal government of Canada has constitutional responsibilities in education. Reference should be made to both the Constitution Acts of 1867 and 1982, as well as the Indian Act.

2. First Nations schools must represent Canada in any pan-Canadian assessments such as PISA. The provinces and territories may be part of any assessment. However, 'Canadian' results must be from the federal or First Nation schools

3. The federal government through its department of Aboriginal Affairs and Northern Development, Canada (AANDC) should be a member of the CMEC.

4. Canada's national First Nations organization, the Assembly of First Nations, should also be a member of the CMEC.

5. 'Canadian' representation at international education conferences should be from the federal government of Canada. Provincial/territorial ministers should also be included as part of the Canadian delegation. However, leadership must come from the federal government of Canada.

6. The CMEC must contact the OECD, UNESCO, and other international organizations to revise past documents that excluded Canadian federal/First Nation schools in their reports and documents.

\section{References}

[1] Council of Ministers of Education, Canada [CMEC]. "Task force for international cooperation on Holocaust education, remembrance, and research. Liaison projects Baseline study, Canada”. CMEC, Toronto, ON, 2008. pp. 8.
[2] Council of Ministers of Education, Canada [CMEC]. "Understandings between the Council of Ministers of Education, Canada and the department of External Affairs". CMEC, Toronto, ON, 1987. pp. 8.

[3] Council of Ministers of Education, Canada [CMEC]. (2014) 'Home page', http://www.cmec.ca/en/ (18 July 2014).

[4] Council of Ministers of Education, Canada [CMEC]. (2013) 'Education at a glance 2013: Highlights for Canada', pp. 1.

http://www.cmec.ca/Publications/Lists/Publications/Attach ments/300/EAG_2013_Canada_EN.pdf (12 December 2013).

[5] Council of Ministers of Education, Canada [CMEC]. "Meeting of the OECD education committee at ministerial level. Investing in competencies for all: Report of the Canadian delegation, Paris, Fr., April 2-4, 2001". CMEC, Toronto, ON, 2001, pp. 1.

[6] Council of Ministers of Education, Canada [CMEC]. "The development and the state of the art of adult education (ALE): Report for Canada. October". CMEC, Toronto, ON, 2008, pp. 1.

[7] Council of Ministers of Education, Canada [CMEC]. "The development of education in Canada. Reports for Canada. Report one: The education systems in Canada Facing the challenges of the twenty-first century. Report two: Inclusive education in Canada - The way of the future. October". CMEC, Toronto, ON, 2008, pp. 7.

[8] Council of Ministers of Education, Canada [CMEC]. "Education in Canada". CMEC, Toronto, ON, 2008, pp. 2.

[9] Council of Ministers of Education, Canada [CMEC]. (2007). Report of the Canadian delegation. "Fifth meeting of Ministers of Education of the Americas, Cartagena, Columbia,, Nov. 14-16, 2007". CMEC, Toronto, ON, 2007, pp. 68.

[10] Council of Ministers of Education, Canada. [CMEC]. (2007). Report for Canada. "UNESCO Seventh Consultation of Member States on the Implementation of the Convention and the Recommendation against Discrimination in Education, September". CMEC, Toronto, ON, 2007, pp. 9.

[11] Council of Ministers of Education, Canada, PanCanadian protocol for collaboration on school curriculum revision, CMEC, Toronto, ON, 2009, pp. 1.

[12] Government of Canada. 'Constitution Acts, 1867 to 1982. VI Distribution of Legislative Powers', $p p$. 1, http://laws-lois.justice.gc.ca.eng/Condt/page4.html\#docCont (15 December 2013).

[13] Government of Canada. 'Part II - Right of the Aboriginal Peoples of Canada', pp. 1,http://lawslois.justice.gc.ca/eng/Const/page-16.html\#docCont, pp. 1 (15 December 2013). 
[14] Aboriginal Affairs and Northern Development Canada [AANDC]. (2010). 'Treaty 5 between Her Majesty the Queen and the Saulteaux and Swampy Cree Tribes of Indians at Beren's River and Norway House with Adhesions', pp. 3. https://www.aadncaandc.gc.ca/eng/1100100028699/1100100028700, (9 December 2013).

[15] Government of Canada. Justice laws website. Indian Act, pp. 1. http://laws-lois.justice.gc.ca/eng/acts/i-5/page35.html\#h-42 (8 November 2013).

[16] Standing Senate Committee on Aboriginal Peoples. Reforming First Nation education: From crisis to hope. Report of the Standing Senate Committee on Aboriginal People. Senate Committee Directorate, Ottawa, ON, 2011, pp. 9.

[17] Aboriginal Affairs and Northern Development Canada [AANDC]. Manitoba region education program, September 1984. Communique by George B. Campbell, Regional Director General, Manitoba Region, Indian Affairs. AANDC, Winnipeg, MB, 1984, pp. 1.

[18] Standing Senate Committee on Aboriginal Peoples (2010) 'Proceedings of the Standing Senate Committee on Aboriginal Peoples. Issue 3 - Evidence - Meeting of April 13, 2010. Ottawa', pp. 9. http://www.parl.gc.ca/Content/ SEN/Committee/403/abor/03evb-e.htm (18 November 2013).

[19] J. Marshall, S. Carr-Stewart, S., \& L. Steeves, Case study: A comparison of resources available for secondlevel education services in Saskatchewan First Nations schools and a Saskatchewan School Division. Paper presented at the Centre for the Study of Living Standards Sessions at the Annual Meeting of the Canadian Economics Association, Quebec City, Quebec, May 28-30, 2010. Session 1, Improving the human capital of Canada's Aboriginal People, Friday, May 28, 2010, 9:00 - 10:30 a.m. St. Catherines, ON, 2010, pp. 12.

[20] Ontario Ministry of Community Safety and Correctional Services. The Office of the Chief Coroner's death review of the youth suicides at the Pikangikum First Nation 2006 - 2008. Ontario Ministry of Community Safety and Correctional Services, Toronto, ON, 2011, pp. 86.

[21] Aboriginal Affairs and Northern Development, Canada [AANDC]. (2011). First Nation elementary and secondary education: Discussion guide. AANDC, Ottawa, ON, 2011, pp. 3.

[22] Standing Senate Committee on Aboriginal Peoples. Reforming First Nation education: From crisis to hope. Report of the Standing Senate Committee on Aboriginal People. Senate Committee Directorate, Ottawa, ON, 2011, pp. 65.

[23] Statistics Canada (2007) 'Programme for international student assessment (PISA)’, pp. 1.

http://www.statcan.gc.ca/cgi-bin/imbd/p2SV.pl?FunctiongetSurvey\&SDDS-5060\&lang-en\&db-imbd\&adm-8\&dis2\#bl (15 November 2013).
[24] Statistics Canada (2007) 'Education indicators in Canada: Report of the Pan-Canadian educators program 2007 - highlights', pp. 2, http://www.statcan.gc.ca/pub/81582-x/2007001/4148950-eng.htm\#8 (18 October 2013).

[25] United Nations Education Scientific and Cultural Organization [UNESCO] (2006). Canada: World data on education, $6^{\text {th }}$ edition, UNESCO International Bureau of Education. Updated version, November, pp. 1. http://www.ibe.unesco.org/Countries/WDE/2006/NORTH _AMERICA/Canada.pdf (4 November 2013).

[26] Council of Ministers of Education, Canada [CMEC]. Report to UNESCO and the UN High Commissioner for human rights education. Report for Canada 2005-2009. CMEC and the Canadian Commission for UNESCO, Toronto, ON, 2010, pp. 1.

[27] Organization for Economic and Cooperative Development [OECD . (2010). The big cost of low educational performance. The long-run economic impact of improving PISA outcomes. OECD, Paris, Fr, 2010, pp. 3.

[28] Canadian Education Statistics Council (2011). Education indicators in Canada: Handbook for the PanCanadian education indicators program. Canadian Education Statistics Council, 2011, Toronto, ON, pp. 36.

[29] C., Inglis, Planning for cultural diversity. Paris, FR: UNESCO: International Institute for Education Planning, 2008, pp. 130.

[30] D., Gerin-Lajoie, Racial and ethnic diversity in schools: The case of English Canada. Prospects, 42, 205220. Paris, Fr: UNESCO, 2012, pp. 208. 